\title{
The Role of Digital Marketing as a Marketing Tool in Hotels in Badung Regency
}

\author{
I Gusti Agung Bagus Mataram ${ }^{1, *}$, I Wayan Jendra ${ }^{1}$, I Wayan Siwantara ${ }^{2}$, Nyoman Indah Kusuma Dewi ${ }^{2}$ \\ ${ }^{1}$ Tourism Department, ${ }^{2}$ Business Administration Department \\ Politeknik Negeri Bali \\ Badung, Indonesia \\ *mataram@pnb.ac.id, wayanjendra@pnb.ac.id, wayansiwantara@pnb.ac.id,ikdewi@pnb.ac.id
}

\begin{abstract}
The purpose of this paper is to explore the role of digital marketing as a marketing tools in hotels in Badung regency. The applications of Internet is vast in every aspect, including the hospitality industries. Marketing is viewed as a very important activity in a hotel. As Internet penetrating every aspects of life, the marketing and the internet have been integrating to become digital marketing. The problem question is the role of digital marketing as a marketing tools in hotels in Badung regency. As the research commenced, the outbreak of Covid-19 pandemic also has begun. The method used in this research is a qualitative case study. The informants are 12 persons each represents and appointed by 12 hotels respectively to explain the digital marketing policy. They are digital marketing manager, digital marketing staffs, and director of sales from various non-star hotels to five-star hotels. The summary of data and information collected then were discussed and correlated with the current phenomenon of digital marketing. The finding was that the digital marketing has a very important role in the hotel industry in the pre-Covid-19 pandemics and even during the Covid-19 pandemics. Most of hotel activities are slow downed and even stopped during the pandemics but the digital marketing activities are maintained and even increased to overcome the effect of the pandemics. The activity is increased due to the owner and the manager are keen to anticipate and pursue sales of post pandemics era. The owners are keen to expend their personal funds to support the survival of the hotels during the pandemics. Most of the digital marketing staffs are on full time job during the pandemics amid the stayed home employees.
\end{abstract}

Keywords-digital marketing, digital marketing role, hotel digital marketing, hotels marketing tools

\section{INTRODUCTION}

Every activity which represented by a department in a company has its owned role. Hence, a marketing department also has an important role in the hospitality industries [1]. The development of technological particularly information and communication technology (ICT) and the intense use of Internet have affected various aspects of activities [2]. The tourism world is no exception.
Hotel as a component of tourism is a business unit which requires a variety of business activities to sustain, one of the sub-activities is marketing. The reliance to the Internet makes information request of hotels raises [3]. Along with the development of Internet technology, businesses, especially hoteliers, naturally take part in utilizing the Internet for marketing, in this case termed digital marketing [4]. The development and penetration of the internet which is increasingly fast has developed the growth of online transactions which in addition to intensifying economic life but will also grow the public into consumers.

During a normal situation marketing has been an important role [5], and since the Internet era the term digital marketing is becoming more important as the centre of marketing activities because the marketing activities is becoming increasingly digital [6]. For some hotels and airlines, the role of digital marketing is very important. However, there are still in certain circumstances some hospitality company get the most clients offline or by a conventional way and conventional marketing activities [7]. Today, the digital marketing is used to promote products online. Currently the usage of digital marketing in hotels has become increasingly very high with Search Engine Optimization (SEO), Social Media Marketing (SMM), and video marketing through you tube. Searching hotels online is the new trend of digital marketing and it increases the possibilities to success to find [8]. In the marketing a hotel, the use and integration of digital marketing is real need [9].

The research object is the role of digital marketing as a marketing tools in hotels specifically in the Badung region. This object is raised because digital marketing and Badung area are important subjects in tourism industries in Bali. Badung regency is the centre of tourism activities in Bali. It is indicated by the most economic activities, income, taxes, number of places to stay, tourist destinations, bank, hospitals, airport etc. [10]. Digitalization or going digital is applied in every aspect of life including marketing. Digital marketing is very important and has changed the marketing strategy in the business world which includes the hotel business [8]. Conventional marketing strategies are no longer sufficient to survive in the business world with intense competition, and therefore hotels must also adjust their marketing strategies by 
utilizing the internet. The Internet through digital media has significantly impacted the way a marketer reaches current customer even the low-income groups [11].

It depends on the hotel's management style, usually it has a division called digital marketing or marketing communication. However, some hotels classifying these marketing division as departments. Nowadays digital marketing plays a very critical role for the success of every business and in the tourism industries as well [5]. The managers should consider and adopt digital marketing to survive current's global market [3]. For its role to be balanced, it is necessary to encourage the role of digital marketing so that the community can also play an active and positive role. Research from various places and various hotels recently in summary have found that the role of digital marketing are very beneficial to the hotel industries [5], from increasing the hotel performance [12] especially the occupancy [13], to maintain customer or customer relationship marketing and increasing business value [14], to increase the accessibility, visibility and satisfaction [15]. The above study was conducted before the Covid-19 pandemics.

The purpose of this study is to explore the role of digital marketing as a marketing tools in hotels in Badung regency. However, throughout the research, the pandemics happened. Hence this study also explore any change of the role throughout the pandemics.

\section{RESEARCH METHODS}

This research will examine the role of digital marketing as a marketing tool in the hospitality sector in Badung Regency with a qualitative case study method. Case studies are used in this research because the focus of this research is to answer the question of the behaviour of the parties to be investigated and it cannot be manipulated, specifically examining only one context and the unclear boundaries between phenomena and contexts to be studied. Multiple case study was chosen as a research strategy because it allows researchers to explore differences in and between cases. The aim is to replicate the results of research between cases. The selection of cases is done carefully, namely by choosing 35 -star hotels, 3 4-star hotels, 3 3-star hotels, and 3 non star hotels so that the total number of hotels to be investigated is 12 hotels.

This study is a qualitative study based on case studies. Case study research is applied as its significance at a theoretical and practical link level [16]. And the methodology consisting of: a) the exploration of the role of present digital marketing; b) semi-structured interviews to the hotelier staffs who knew and experienced the digital marketing in the hotels studied.

The research location are hotels in Badung regency. The hotels used as research locations are 3 5-star, 4-star, 3-star hotels and non-star hotels, hence the total number of hotels to be studied is 12 hotels in the Badung Regency area. The selection of this hotel is based on the willingness of the hotel to be used as a research location. Different levels of hotels are used to determine whether there are differences in the implementation of digital marketing in these hotels.
Data collected by in-depth interview. A staff in a hotel was appointed by the hotel as an informant and interviewed, respectively. The informants are people who knows and experienced the market, marketing, social media, competitors, potential guests and all market related knowledge. The informants are those involved in the digital marketing, they can be the staff from the digital marketing division or department, marketing department, sales department or reservation department who are considered know well on the digital marketing by the hotel management.

\section{RESULTS AND DISCUSSION}

It is found that the common role of marketing department or the marketing activity which was responsible to the sales achievement in a company [11], performance [12], as well as occupancy [13] has decreased significantly as the pandemic's consequences.

It is found that the role of the digital marketing staff of the hotels in Badung regency is still active and important during the pandemics which is contrary compared with other staffs from different departments. In the normal situation almost all the hotel's activities which represented by respective department have important role and all employees worked full weekdays working schedule. While, in the abnormal situation, in this case the Covid-19 pandemics it is found that some of the activities are in lame-like. Some department became inactive due to the absence of the tourists. Kitchen, restaurant, housekeeping, room attendant are the examples of departments or divisions which nearly shut downed completely except some very minor activity such as keeping the equipment clean and ready to gear up when the situation turning normal again.

Some small part of departments or divisions like the security and the engineering are still active. The security department reduced staffs on duty to secure the hotel's premises. "However, we have to secure our properties, that's why we are still put most of the security staff on job," explained the hotel through the informant.

A director of sales explained: "We don't know when the pandemics will end. That's why we have to be prepared to be able to start immediately as soon as it is normal". Hence some staffs of engineering keep on duty to make sure all the hotel equipment is in a ready to use condition.

However, some innovative and sometimes brilliant ideas came up from this pandemic's situation. There was a brilliant hotel management policy in Ubud village during this Covid-19 pandemic. Instead of laying off its employees totally, they made use the pandemics time to rejuvenate the buildings using the staffs those do not have job at the pandemic's situation. Therefore, they do not need to lay off employees and, they do not need to hesitate to bother the guests because of the noise caused by construction activities. But this took place for 2 months only. Thereafter the management should apply like other hotels do. "We wish to make use of the staff, so we don't spend some rehabilitation money to outsourcing parties," said the manager of one hotel. 
While the hotel is empty the digital marketing is very busy to create activities to overcome the potentially being drowned or collapsed amid this situation. By the collaboration with other departments the activities can be creating and promoting innovative products such as use the pastry and kitchen division to produce and sells take away foods, and pro-actively hunting for the new potential client and evaluating bad comments from the social media [2]. Open the swimming pool for public also an option taken by some hotels. Other innovative products also can be made in the reservation and payments side, there is a phenomenon during the Covid-19 pandemics among the hotel industries which is called "pay now stay later". This payment and reservation method is mainly aiming to keep the cash to flow in the hotel so the hotel can keep its premises alive. Although the pay now stay later product is reservations and sales department job, but the digital marketing also has role to promote it. The hotels have made appropriate short time diversification action [2] to keep varies strategies to support survival performance [13].

Some hotel owner affords to pay the salaries of the employees even there is no guest at all stay in the hotel or zero guest. However, they did not pay $100 \%$. Some pay $70 \%, 50 \%$, and $30 \%$. Beside the reduction of the salary, usually the management will reduce the weekdays of the employees by scheduling them in a 2- or 3-days' work in a week. However only a few owners afford to pay their employees amid zero guest. A digital marketing of a hotel in Nusa Dua area said:" My boss is paying the salary for digital marketing activities during the pandemics using his own money". This indicates the important role of digital marketing.

Covid-19 has made most departments in a hotel are partially shut downed and staffs are mostly laid off at home with reduced pay or even not paid. However, the different phenomenon has emerged to the digital marketing activities. All the hotels involved in this research are keeping their digital marketing activities are in full pace. Large hotels spent more budget for its activities in digital marketing than small hotels. A hotel's digital marketing department in Nusa Dua area even got more budget during this pandemic. Even some digital marketing departments got their largest ever budget.

The hotels are relying on the digital marketing activities to overcome the Covid-19 negative impact in this case maintaining the market potencies. From now on, companies must follow technological developments such as digital marketing media to increase their marketing [17]. Indirectly the advances in ICT plays an important role in the development of digital marketing, especially during the Covid-19 Pandemic [17]. The presence of the hotel to the potential customer need to be nurtured even the current market still in rest. The digital marketing needs to keep the word of mouth like to continue buzzing [18] along with social media [17] and mobile apps [9]. The promotion should also include hygiene and cleanliness [19]. So that when the situation is normal, the hotel will not need to gear up from the very beginning.
While the role of digital marketing keeping the accessibility and the visibility [15] of the hotel is relatively in the same pace. This digital marketing activities also has become another role which is to maintain the relationship with the customers.

\section{CONCLUSION}

Digital marketing as a marketing tools for hotels in Badung area is very important. Even it is becoming more important during the Covid-19 pandemics. The role of digital marketing as a marketing tools is described as follows.

- As a tool, digital marketing suite the Internet to enable making use of Internet as a marketing media such as marketing in social media particularly Facebook, Instagram, or marketing in other media such as Trip Advisor, Online Travel Agents, Search Engine Optimizer. These activities also support the existence of the hotel to prepare for post pandemics period by maintaining the relationship with the customers. Therefore, the role of digital marketing as a marketing tools become even more important due to the pandemics.

- As a marketing tools for assisting the hotel to survive during this Covid-19 pandemic, by promoting unusual innovative product that a hotel has created such as a takeaway food, swimming pool open to public, half day use room, pay now stay later etc.

- As a marketing tools, digital marketing is indicated as an important department or division so that it does not need to lay off its employees. And it gets full budget to operate during the pandemics. This indicates the important role of digital marketing department for survival activities.

\section{ACKNOWLEDGMENT}

Many thank you to the Indonesian government DIPA 2020 which has sponsored this research through the Bali State Polytechnic.

\section{REFERENCES}

[1] J.C. Maxwell, A treatise on electricity and magnetism, Oxford: Clarendon Press, 1873.

[2] I.V. Hristoforova, L.V. Silcheva, T.N. Arkhipova, A.B. Demenkova, and E.Y. Nikolskaya, "Improvement of Digital Technologies in Marketing Communications of Tourism and Hospitality Enterprises," in Journal of Environmental Management and Tourism, vol. X, 2019.

[3] Y. Yorozu, M. Hirano, K. Oka, and Y. Tagawa, "Electron spectroscopy studies on magneto-optical media and plastic substrate interface," IEEE Transl. J. Magn. Japan, vol. 2, pp. 740-741, August 1987.

[4] N Scott, E. Laws and P Boksberger, "The Marketing of Hospitality and Leisure Experiences," in Journal of Hospitality Marketing \& Management, vol. 18, Issue 2-3, p 99-110, 2009.

[5] L. Patrutiu-Baltes, Inbound Marketing - the most important digital marketing strategy, Bulletin of the Transilvania University of Braşov Series V: Economic Sciences, vol. 9, 2016. 
[6] R.A. Leite and A Azevedo, "The Role of Digital Marketing: A perspective from Porto Hotels' Managers," in International Journal of Marketing, Communication and New Media, vol 2, 2017.

[7] P.W.P. Paramita, I P. Astawa, and I G.A.B. Mataram," Implementation of Offline Travel Agent Promotion Model To Increase Room Occupancy At The Ritz-Carlton, Bali”, unpublished.

[8] G. Kaur, "The importance of digital marketing in the tourism industry," International Journal of Research-Granthaalayah, vol. 5, no. 6, 72-77, 2017.

[9] M. Alghizzawi, "The role of digital marketing in consumer behavior: A survey," in International Journal of Information Technology and Language Studies, vol. 3, issue. 1, pp. 24-31, 2019.

[10] Indonesia Central Bank, The Economic Report for Bali Province, 2019

[11] G.M. Alves, B.M. Sousa and A. Machado, "The Role of Digital Marketing and Online Relationship Quality in Social Tourism: A Tourism for All Case Study," Digital marketing strategies for tourism, hospitality, and airline industrie, 2020.

[12] S.M. González and J.B. Gidumal, "A model that connects information technology and hotel performance," Tourism Management, vol. 53, April 2016.
[13] P.D. Pelsmacker, S. Tilburg, and C. Holthof, "Digital marketing strategies, online reviews and hotel performance," International Journa of Hospitality Management, vol. 72, June 2018.

[14] T.H Jung, E.M. Ineson, and E. Green, "Online social networking: Relationship marketing in UK hotels," Journal of Marketing Management, vol. 29, 2013.

[15] A. Bethapudi, "The Role of ICT in Tourism Industry," Journal of Applied Economics and Business, vol.1, issue. 4, December 2013.

[16] P. Kotler, J.T. Bowen, J. Makens, and S. Baloglu, Marketing for Hospitality and Tourism, Boston: Prentice Hall, 2010.

[17] R.E. Junusi, "Digital Marketing During the Pandemic Period; A Study of Islamic Perspective," Journal of Digital Marketing and Halal Industry, vol. 2, no. 1, 2020.

[18] B.A. Sparks and V. Browning, "The impact of online reviews on hotel booking intentions and perception of trust," in Journal of Tourism Management," vol. 32, 2016.

[19] Y. Jiang and J Wen, "Effects of Covid-19 on hotel marketing and management: a perspective article," in International Journal of Contemporary Hospitality Management, vol. 32, 2020. 